\title{
OPEN Denitrifying bacterial communities in surface-flow constructed wetlands during different seasons: characteristics and relationships with environment factors
}

Jia-ming Wei ${ }^{1,2}$, Li-juan Cui ${ }^{3,4,5 凶}$, Wei Li ${ }^{3,4,5}$, Yun-mei Ping ${ }^{3,4,5}$ \& Wan $\mathrm{Li}^{1,2}$

Denitrification is an important part of the nitrogen cycle and the key step to removal of nitrogen in surface-flow wetlands. In this study, we explored space-time analysis with high-throughput sequencing to elucidate the relationships between denitrifying bacteria community structures and environmental factors during different seasons. Our results showed that along the flow direction of different processing units, there were dynamic changes in physical and chemical indicators. The bacterial abundance indexes (ACEs) in May, August, and October were 686.8, 686.8, and 996.2, respectively, whereas the Shannon-Weiner indexes were 3.718, 4.303, and 4.432, respectively. Along the flow direction, the denitrifying bacterial abundance initially increased and then decreased subsequently during the same months, although diversity tended to increase. The abundance showed similar changes during the different months. Surface flow wetlands mainly contained the following denitrifying bacteria genus: unclassified Bacteria (37.12\%), unclassified Proteobacteria (18.16\%), Dechloromonas (16.21\%), unranked environmental samples $(12.51 \%)$, unclassified Betaproteobacteria (9.73\%), unclassified Rhodocyclaceae (2.14\%), and Rhodanobacter (1.51\%). During different seasons, the same unit showed alternating changes, and during the same season, bacterial community structures were influenced by the second genus proportion in different processing units. ACEs were strongly correlated with temperature, dissolved oxygen, and $\mathrm{pH}$. Bacterial diversity was strongly correlated with temperature, electrical conductivity, $\mathrm{pH}$, and oxidation reduction potential. Denitrifying bacteria are greatly affected by environmental factors such as temperature and $\mathrm{pH}$.

Bacteria in constructed wetland participate in the decomposition and transformation of pollutants, which is one of the key mechanisms to remove pollution. Some reports have shown that denitrifying bacteria account for $60-86 \%$ of total nitrogen removal ${ }^{1}$. Denitrifying microorganisms exhibit rich species diversity ${ }^{2}$, although in some Paleozoic fungus groups or specific fungi have some roles in denitrification ${ }^{3}$, denitrification is primarily a bacteria activity, and more than 50 species of bacteria have been shown to have denitrifying activities ${ }^{4}$. Therefore, it is important to study the denitrifying bacterial community structures of wetlands. Lee and Kang used high-throughput sequencing to identify denitrifying bacterial community structures at different soil depths ${ }^{5}$, and Wang et al. ${ }^{6}$ revealed the wetland community structures of autotrophic denitrification bacteria. Additionally, Cao et al. ${ }^{7}$ assessed the denitrifying community structures of natural wetlands and constructed wetlands, and $\mathrm{Fu}$ et al. ${ }^{8}$ discussed different carbon sources for constructed wetland plants and denitrifying community structures. Santoro et al. ${ }^{9}$ used nirS/K as molecular markers; the salinity/denitrifying nitrite concentration gradient of the coastal wetland aquifer can be used to identify microbial diversity, with unique microbial groups identified at a very low space scale ( $40 \mathrm{~m}$ distance). Recent studies have focused on different types of wetlands and vertical depth, as well as the denitrifying community structures under different environmental conditions for both

\footnotetext{
${ }^{1}$ Beijing Construction Engineering Group Environmental Remediation Co. Ltd, Beijing 100051, China. ${ }^{2}$ National Engineering Laboratory for Site Remediation Technologies, Beijing 100872, China. ${ }^{3}$ Institute of Wetland Research, Chinese Academy of Forestry, Beijing 100091, China. ${ }^{4}$ The Beijing Key Laboratory of Wetland Ecological Function and Restoration, Beijing 100091, China. ${ }^{5}$ Beijing Hanshiqiao National Wetland Ecosystem Research Station, Beijing 101399, China. ${ }^{\square}$ email: wetlands108@126.com
} 


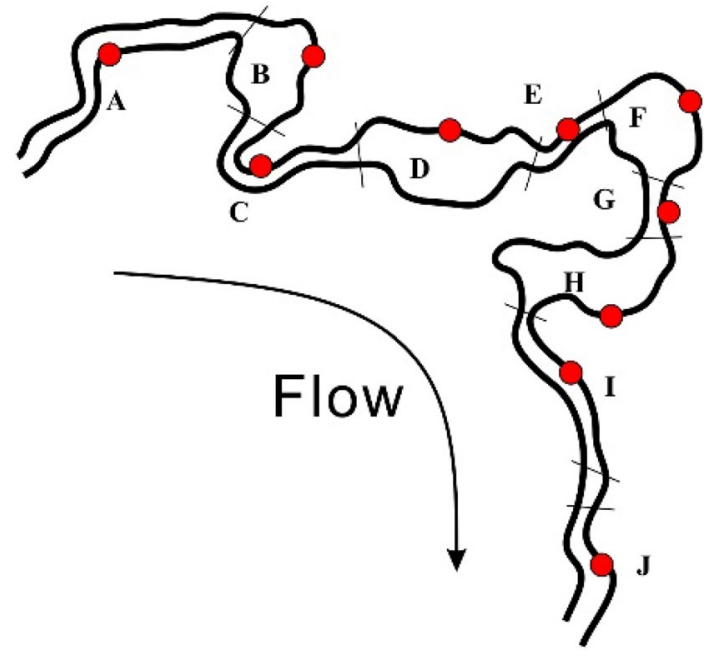

Figure 1. Sample locations at the surface-flow constructed wetland.

natural wetlands and constructed wetland. Fu et al. ${ }^{10}$ found that aerobic denitrifiers were entirely dominant in the middle and upper layers of the constructed wetland, where obligate halophilic, aerobic denitrifiers Zobellella occurred. Zhang et al. ${ }^{11}$ found that the variations of bacterial community presented a significant seasonal change and Gillisia (belonging to Bacteroidetes) and Woeseia (affiliating with Gammaproteobacteria) were the two primary components in the rhizosphere soils.

At present, most studies focus on the community structure of denitrifying bacteria in constructed wetland and its response to a single environmental factor, but do not discuss the community structure and spatial distribution of denitrifying bacteria in constructed wetland in different seasons ${ }^{1}$. We used Miseq high-throughput sequencing to evaluate the denitrifying bacterial community structure during different seasons in different processing units through a space-time three-dimensional analysis using redundancy analysis (RDA). We also explored the relationships of these community structures with environmental factors in order to evaluate the surface flow wetland spatial distributions of denitrifying bacterial community structures.

\section{Methods}

Experimental site and sample design. The study area was located in Shunyi district of Beijing, Beijing Wildlife Rescue and Breeding Center, a surface-flow wetland $\left(6^{\prime} 14.40^{\prime \prime} 40^{\circ} \mathrm{N}, 42^{\prime} 35.71^{\prime \prime} 116^{\circ} \mathrm{E}\right)$. Because the Beijing Wildlife Rescue and Breeding Center was not open to tourists, the influence of artificial factors on the bacteria environment was minimized. Figure 1 shows the layout of the flow wetlands (A-J). The main species of each units were evaluated: Typha orientalis, Eichhornia crassipes, Acorus calamus, Sagittaria sagittifolia, Eleocharis congesta, Nymphoides peltatum, Oenanthe javanica, Monochoria korsakowii, Sparganium stoloniferum, and Iris tectorum. In August (summer), October 2015 (autumn), and May 2016 (spring), The surface litter was stripped during samping, and the sediments with the depth of $0-10 \mathrm{~cm}$ were sampled. Overlying water in the sediment around the site was collected in triplicate. Sediment samples were cryopreserved at $-80^{\circ} \mathrm{C}$ until molecular biology analysis. For environmental factor analysis, water samples were stored at $4{ }^{\circ} \mathrm{C}$.

DNA extraction, polymerase chain reaction (PCR) amplification, and sequencing. DNA extraction was carried out using an Omega Soil DNA Kit (Omega Bio-tek, Norcross, GA, USA) using the following primers $^{12}$ : cd3aF, 5'-GTSAACGTSAAGGARACSGG-3',R3cd, 5'-GASTTCGGRTGSGTCTTGA-3'. PCR was carried out using TransGen AP221-02, with TransStart Fastpfu DNA polymerase in a 20- $\mu \mathrm{L}$ reaction system containing $5 \times$ FastPfu buffer $(4 \mu \mathrm{L}), 2.5 \mathrm{mM}$ dNTPs $(2 \mu \mathrm{L})$, forward primer $(5 \mu \mathrm{M} ; 0.8 \mu \mathrm{L})$, reverse primer $(5 \mu \mathrm{M} ; 0.8$ $\mu \mathrm{L})$, FastPfu polymerase $(0.4 \mu \mathrm{L})$, template DNA $(10 \mathrm{ng})$, and $\mathrm{dd}_{2} \mathrm{O}$ to $20 \mu \mathrm{L}$. PCR was carried out with an ABI GeneAmp 9700 instrument using the following parameters: $95^{\circ} \mathrm{C}$ for $3 \mathrm{~min} ; 27$ cycles of $95^{\circ} \mathrm{C}$ for $30 \mathrm{~s}, 55^{\circ} \mathrm{C}$ for $30 \mathrm{~s}, 72{ }^{\circ} \mathrm{C}$ for $45 \mathrm{~s}$; and $72{ }^{\circ} \mathrm{C}$ for $10 \mathrm{~min}$. All samples were assessed using AxyPrepDNA gel recovery kits (Axygen Biosciences, Union City, CA, USA), and PCR products were eluted with Tris HCl solution and detected by $2 \%$ agarose gel electrophoresis. Quantitative PCR was carried out using a QuantiFluor-ST blue fluorescence system (Promega, Madison, WI, USA). Using bridge PCR and reversible end analysis ${ }^{13}$, in combination with the Illumina MiSeq platform and standard methods for high-throughput sequencing, we obtained data from each round of PCR and then analyzed the template DNA sequences.

Water physicochemical properties. Dissolved oxygen (DO), salinity, oxidation reduction potential (ORP), pH, electrical conductivity (SpCond), total dissolved solids (TDSs), temperature, and other indicators of water quality were analyzed using a portable multiparameter YSI-exobiology instrument (YSI, USA). Determination of total nitrogen (TN) was carried out using a SMARTCHEM200 automatic chemical analyzer (WestCo, 


\begin{tabular}{|c|c|c|c|c|c|c|c|c|c|c|c|c|c|c|c|c|c|c|c|c|c|c|c|c|c|c|c|}
\hline \multirow{2}{*}{$\begin{array}{l}\text { Wetland } \\
\text { location }\end{array}$} & \multicolumn{3}{|c|}{$\mathrm{DO} / \mathrm{mg} \cdot \mathrm{L}^{-1}$} & \multicolumn{3}{|l|}{ ORP/mV } & \multicolumn{3}{|l|}{$\mathrm{pH}$} & \multicolumn{3}{|c|}{ Salinity/ng $\cdot \mathbf{L}^{-1}$} & \multicolumn{3}{|c|}{ SpCond $/ \mathrm{mS} \cdot \mathrm{cm}^{-1}$} & \multicolumn{3}{|c|}{$\mathrm{TDS} / \mathrm{g} \cdot \mathrm{L}^{-1}$} & \multicolumn{3}{|l|}{ Temp $/{ }^{\circ} \mathrm{C}$} & \multicolumn{3}{|c|}{$\mathrm{TN} / \mathrm{mg}_{\mathrm{L}}^{-1}$} & \multicolumn{3}{|c|}{$\mathrm{TOC} / \mathbf{m g} \cdot \mathrm{L}^{-1}$} \\
\hline & 5 & 8 & 10 & 5 & 8 & 10 & 5 & 8 & 10 & 5 & 8 & 10 & 5 & 8 & 10 & 5 & 8 & 10 & 5 & 8 & 10 & 5 & 8 & 10 & 5 & 8 & 10 \\
\hline A & 2.281 & 3.917 & 2.417 & -59.000 & -57.800 & \begin{tabular}{|l|}
-144.633 \\
\end{tabular} & 7.673 & 10.223 & 7.717 & 0.313 & 0.277 & 0.227 & 0.640 & 0.574 & 0.469 & 0.416 & 0.367 & 0.300 & 16.053 & 28.075 & 16.835 & 1.956 & 1.600 & 2.398 & 5.525 & 6.996 & 5.683 \\
\hline B & 2.644 & 3.983 & 1.810 & -134.000 & -55.667 & -261.833 & 7.530 & 10.173 & 7.650 & 0.300 & 0.270 & 0.220 & 0.614 & 0.573 & 0.455 & 0.399 & 0.367 & 0.291 & 16.103 & 28.099 & 17.444 & 4.572 & 1.586 & 1.687 & 7.353 & 8.715 & 5.133 \\
\hline C & 3.085 & 4.040 & 0.963 & -57.667 & -54.300 & -270.000 & 7.553 & 10.133 & 7.610 & 0.290 & 0.270 & 0.227 & 0.597 & 0.572 & 0.464 & 0.388 & 0.366 & 0.297 & 16.193 & 28.207 & 16.007 & 2.669 & 1.282 & 3.420 & 5.358 & 8.277 & 5.430 \\
\hline D & 2.921 & 4.083 & 1.003 & -21.333 & -53.433 & -236.300 & 7.897 & 10.107 & 7.693 & 0.273 & 0.270 & 0.230 & 0.561 & 0.571 & 0.467 & 0.365 & 0.366 & 0.299 & 19.073 & 28.206 & 15.373 & 2.281 & 0.822 & 2.902 & 6.937 & 4.592 & 6.237 \\
\hline E & 2.366 & 4.130 & 0.853 & -47.667 & -52.633 & -206.300 & 7.883 & 10.077 & 7.677 & 0.267 & 0.270 & 0.230 & 0.550 & 0.570 & 0.467 & 0.358 & 0.365 & 0.299 & 16.710 & 28.375 & 15.411 & 2.301 & 0.810 & 2.070 & 7.322 & 4.540 & 6.969 \\
\hline $\mathrm{F}$ & 1.601 & 4.170 & 1.140 & -30.333 & -52.033 & -186.967 & 7.657 & 10.050 & 7.637 & 0.283 & 0.270 & 0.230 & 0.582 & 0.569 & 0.466 & 0.378 & 0.364 & 0.298 & 16.583 & 28.245 & 15.695 & 1.310 & 0.546 & 1.017 & 7.090 & 4.684 & 5.426 \\
\hline G & 1.321 & 4.203 & 1.490 & -8.667 & -51.600 & -218.667 & 7.557 & 10.030 & 7.553 & 0.290 & 0.270 & 0.230 & 0.595 & 0.567 & 0.467 & 0.387 & 0.363 & 0.299 & 17.273 & 28.372 & 15.781 & 0.949 & 0.583 & 0.894 & 6.989 & 4.665 & 4.226 \\
\hline $\mathrm{H}$ & 1.095 & 4.240 & 2.307 & -19.000 & -51.300 & -206.267 & 7.477 & 10.017 & 7.490 & 0.280 & 0.270 & 0.227 & 0.577 & 0.565 & 0.466 & 0.375 & 0.362 & 0.298 & 18.097 & 28.290 & 15.697 & 1.124 & 0.519 & 0.808 & 7.536 & 7.166 & 4.280 \\
\hline I & 1.168 & 4.273 & 1.697 & -21.667 & -51.100 & -211.733 & 7.437 & 10.003 & 7.573 & 0.283 & 0.270 & 0.230 & 0.579 & 0.564 & 0.466 & 0.377 & 0.361 & 0.298 & 19.010 & 28.439 & 15.741 & 1.222 & 0.540 & 0.690 & 8.724 & 7.578 & 5.323 \\
\hline$J$ & 1.891 & 4.300 & 2.540 & -79.333 & -50.933 & -208.467 & 7.297 & 9.990 & 7.620 & 0.317 & 0.270 & 0.227 & 0.644 & 0.563 & 0.465 & 0.419 & 0.360 & 0.297 & 15.167 & 28.291 & 14.901 & 1.623 & 0.595 & 0.752 & 9.036 & 8.349 & 6.099 \\
\hline
\end{tabular}

Table 1. Physicochemical characteristics of the surface-flow constructed wetlands in each unit. (5: May; 8: August; 10: October).

USA). Total organic carbon (TOC) using the determination of total organic carbon analyzer (Elementar, Germany).

Statistical analysis. Statistical analysis of the community composition of each sample was carried out using the Qiime platform and RDP Classifier ${ }^{14}$ Bayesian algorithm based on a 97\% similarity level for operational taxonomic units (OTUs) in representative sequence taxonomical analysis ${ }^{15}$ and SILVA databases. If the taxonomic databases in some taxonomic lineages had no scientific name for class, the tag "norank" was used. Additionally, the classification was marked as "unclassified" in the classification score at a particular level was low.

$\mathrm{R}$ language was used to generate all optimized sequence maps of OTUs using the obtained sequences for OTUs with similarities of more than $97 \%$. OTUs with similarity levels of $97 \%$ or more were further analyzed using R language ${ }^{16}$, the ACE index (estimated OTU number) in the community, Shannon-Weiner index ( $\mathrm{H}^{\prime}$; a bacterial diversity index; larger values indicate higher community diversity).

Differences among denitrifying bacterial communities were evaluated using $\mathrm{R}$ language, and correlations among water index parameters and bacterial community structures were assessed using Pearson correlation analysis. R language with nonmetric multidimensional scaling analysis and principal component analysis (PCA) were used to evaluate environmental factors. Canoco 5 with redundancy analysis (RDA) was used to assess water factors and the relationships between the denitrifying bacterial community and aquatic environment.

\section{Results and discussion}

Physicochemical properties of water. Physicochemical properties of water and associated environmental factors according to the flow directions of surface flow wetlands are shown in Table 1. Analysis of variance for indexes with $p$ values of less than 0.05 showed that all indexes exhibited large variations during different months.

Some indexes exhibited large variations during different months according to the flow directions of surface flow wetlands. For example, DO was first reduced and then increased in May, but increased in August and showed differences compared with that in May and October. The salinity was first reduced and then increased in May but then remained stable from August to October. Some indexes showed similar changes according to the flow directions of surface flow wetlands. For example, ORP showed an initial decrease followed by an increase. At the same time, $\mathrm{pH}$, SpCond, TDSs, and TN showed reduced variability over time. The changes in temperature were minimal, although the temperature was higher in the summer and autumn than in the spring.

Surface flow wetlands are in direct contact with the environment and are greatly influenced by outside environmental factors ${ }^{17}$. Thus, most physicochemical factors of the water samples showed large variability.

Denitrifying bacteria diversity and abundance. For 10 samples from different seasons showing 97\% similarity in clustering analysis, the numbers of OTUs differed in May, August, and October (575, 869, and 741, respectively), and the Fig. 2 showed that the denitrifying bacterial abundance indexes (ACEs) were 686.8, 996.2, and 887.3 in May, August, and October, respectively. Additionally, the Shannon-Weiner indexes $\left(\mathrm{H}^{\prime}\right)$ were 3.718, 4.303 , and 4.432, respectively, indicating that the abundance tended to increase initially, followed by a decrease, and diversity tended to increase. The different seasons affected both the denitrifying bacteria abundance and diversity. Abundance was the largest in August, but its diversity was lower than that in October. These data suggested that the main species became dominant during August, affecting the structure of the denitrifying bacteria.

For different processing units, the abundance and diversity of denitrifying bacteria varied slightly; both the $\mathrm{ACE}$ and $\mathrm{H}^{\prime}$ index showed low variability. The units $\mathrm{F}, \mathrm{H}$, and J showed greater declines than the initial values. In May, the ACE index peaked, with a value of 841 at location I. In August, the ACE index peaked at location E (1251), and that in October peaked at location G (1042). In different months, denitrifying bacteria abundances showed similar changes. Because bacterial diversity in the flowing water and static water were affected by different factors, the surface flow wetlands will be susceptible to various factors, and the bacterial community interactions with internal and external environmental factors will be important for bacterial survival ${ }^{18}$. Additionally, the number of constructed wetland bacteria decreases as the depth and distance increases ${ }^{19,20}$, suggesting that denitrifying bacteria may be affected by physical and chemical indicators of changes in water. 


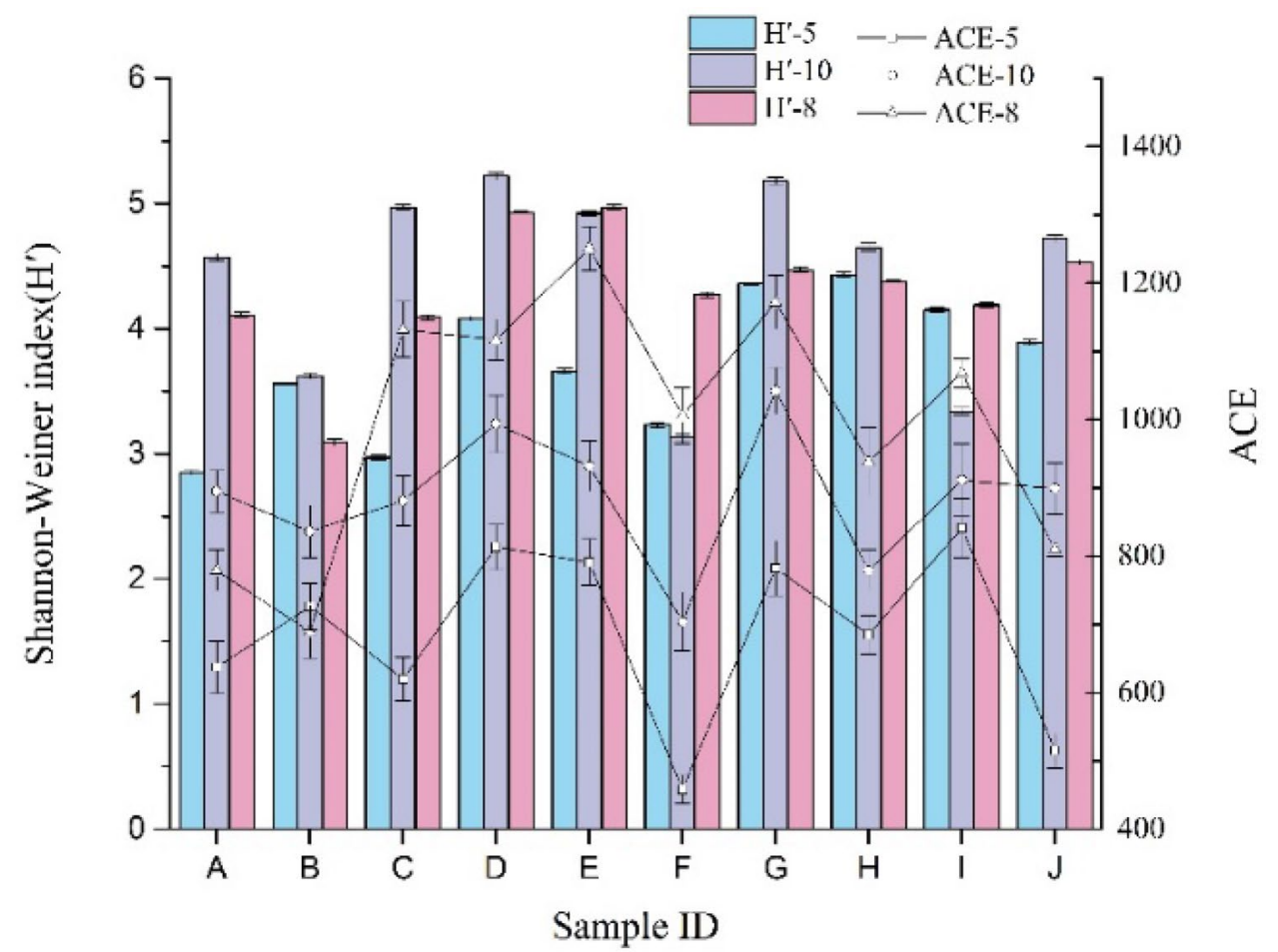

Figure 2. Biodiversity and abundance of the surface-flow constructed wetland in each unit.
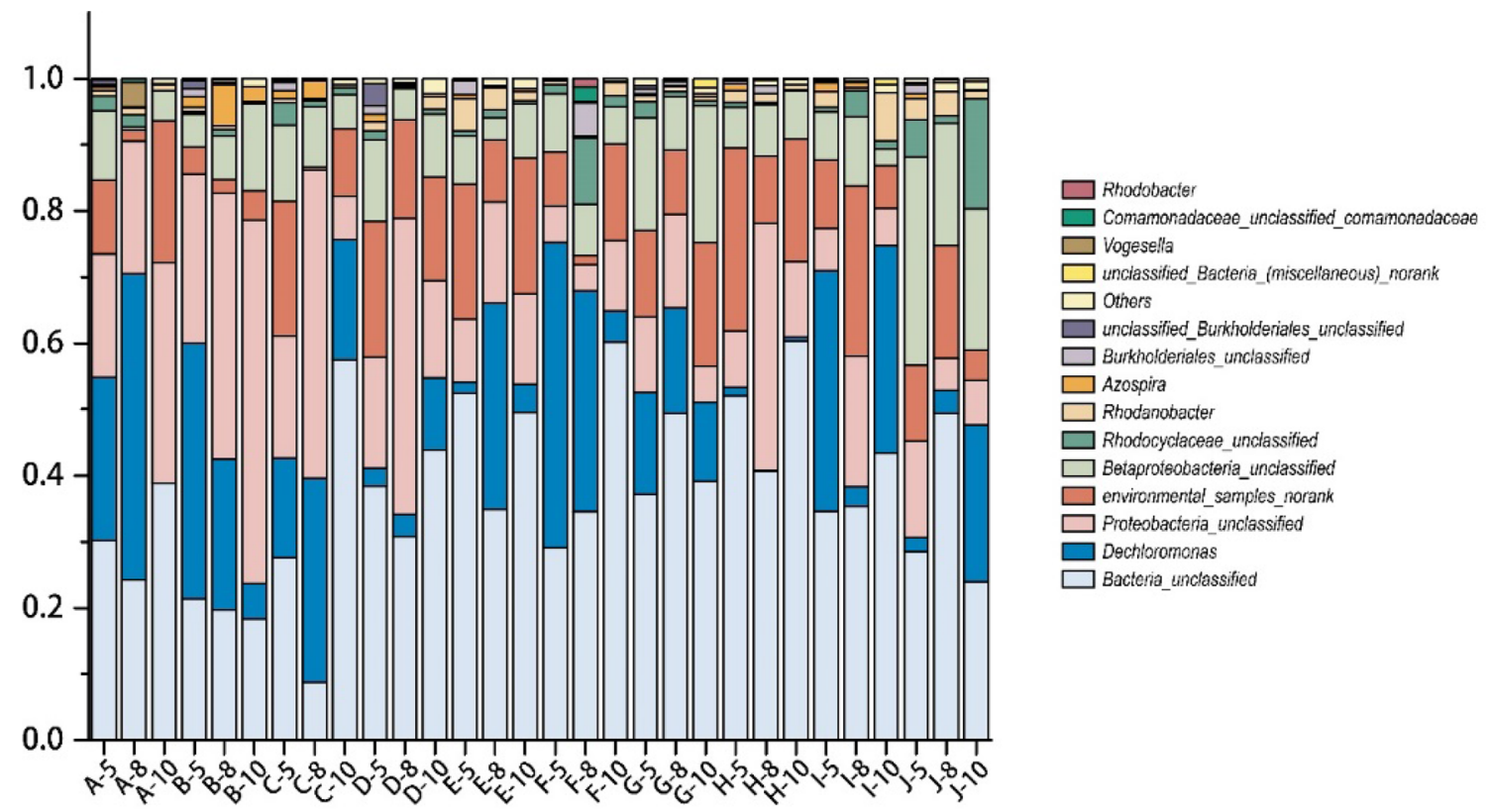

Figure 3. Community structure of the surface-flow constructed wetland in each unit.

Community structure of denitrifying bacteria. Similar OTUs ( $97 \%$ similarity) were identified by sequencing. Database analysis of sequence alignment results revealed that there were many bacteria in the environmental samples that could not be cultivated but that showed high similarity; thus, the denitrifying bacteria were mostly present in the surface flow wetlands and were not cultured. Figure 3 shows statistical analysis of the denitrifying bacterial categories in a histogram format. During the different months, OTUs mainly belonged to seven genera: unclassified bacteria (37.12\%), unclassified Proteobacteria (18.16\%), Dechloromonas (16.21\%), unranked environmental samples (12.51\%), unclassified Betaproteobacteria (9.73\%), unclassified Rhodocyclaceae (2.14\%), Rhodanobacter (1.51\%), and other genera (2.62\%, representing less than $1 \%$ each). Several 

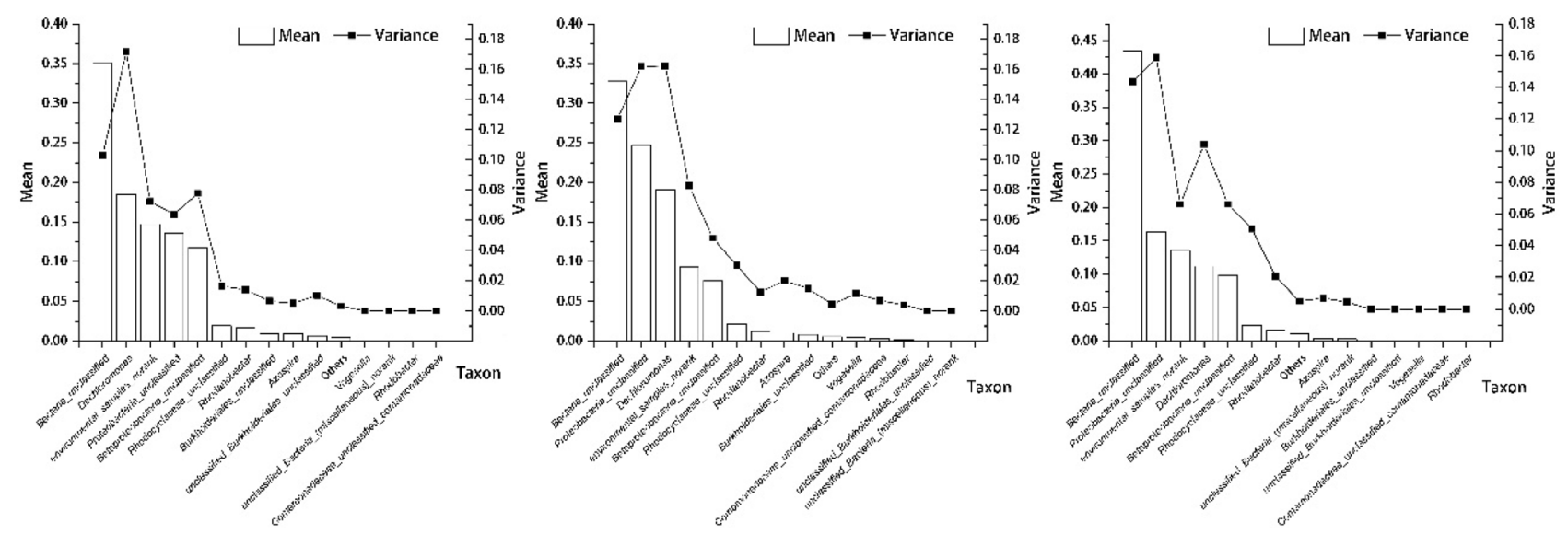

Figure 4. Mean and variance of different denitrifying bacterial taxa in the surface-flow constructed wetland (May, August, and October).

genera have also been found in surface flow wetlands ${ }^{21}$ and other types of constructed wetlands ${ }^{22-24}$, albeit with different proportions.

The same processing units showed different denitrifying bacterial community structures during different seasons and were always changing. Unclassified bacteria showed a greater weight during May for the A processing unit, although its weight was lower than that of Dechloromonas in August. In October, unclassified bacteria had become the most dominant group, and the proportion of Dechloromonas was extremely low. For the B processing unit, from May to October, the proportion of Dechloromonas was decreased, and the proportion of unclassified Proteobacteria was increased, overtaking Dechloromonas. For the $\mathrm{C}$ and D processing units, unclassified Proteobacteria were dominant in May, and unclassified bacteria were dominant in August and October. For the E, G, $\mathrm{H}, \mathrm{I}$, and J processing units, unclassified bacteria were dominant at all time points. For the F processing unit, the bacterial groups were similar to those of the B processing unit, with proportion of Dechloromonas decreasing and the proportion of unclassified bacteria increasing in October.

Figure 4 shows the means and variances of denitrifying bacteria genus proportions among different processing units and seasons. The means and variances of the dominant genus were large at the same time during different seasons. Thus, the dominant genus often determined the changes in denitrifying bacteria community structures during different seasons in the same unit. However, the greatest variance was observed in the genus Dechloromonas, which was the second most dominant genus in May. This suggested that this genus showed greater changes in different processing units than others. In August, the largest variances were observed in the genus Dechloromonas and in unclassified Proteobacteria, which had lower means than unclassified bacteria. Similar results were observed in October. The largest variance was observed in unclassified Proteobacteria, indicating that the denitrifying bacterial community structures were affected by the second dominant genus over time in the different processing units.

For the denitrifying bacteria community structures in different months, we used nonmetric multidimensional scaling to determine the similarities between different processing units during the same months. As shown in Fig. 5, in May, A, B, C, and E showed high similarity, whereas other samples were more dispersed. The distances between $\mathrm{D}$ and $\mathrm{H}$ and between $\mathrm{G}$ and I were shorter than the other distances. F and J were alone in a group. Sample distributions were concentrated in August; C, D, E, F, G, H, and I were relatively similar, and D and E showed maximum similarity. A and B showed some similarity. In contrast, J was distinct. In October, distributions were more dispersed, and the distances between two points were not relatively similar, whereas the differences between the various processing units were higher.

Relationships between denitrifying bacteria and environmental factors. Next, we carried out PCA analysis to determine the main factors affecting denitrifying bacteria. After maximum variance orthogonal rotating $(p=0.05)$, there were two principal component eigenvalues that were greater than the average. The two top principal components contributed to $53.9 \%$ and $28.7 \%$ of the variance. The first principal component mainly reflected SpCond, TDSs, ORP, and salinity (factor loading was $0.409,0.403,0.398$, and 0.403 , respectively), and the second principal component reflected DO, TN, $\mathrm{pH}$, and temperature (factor loading was $0.449,0.449,0.465$, and 0.446 , respectively). The load distribution characteristics of different environmental factors showed that the surface flow wetlands were affected by the main environmental factors, including temperature, SpCond, DO, $\mathrm{pH}$, ORP, and TN (Fig. 6).

Table 2 shows bacterial abundance indexes and $\mathrm{H}^{\prime}$ index for different external environmental factors, as analyzed by Pearson correlation analysis. The results showed that the bacterial abundance was strongly correlated with temperature, $\mathrm{DO}$, and $\mathrm{pH}$, and $\mathrm{H}^{\prime}$ was strongly correlated with all parameters except $\mathrm{TN}$.

RDA was performed (Fig. 7) for analysis of community distributions and the relationships among environmental factors. For screening of the physicochemical factors of water and the proportions of denitrifying bacterial genera, standardization to center (Monte Carlo permutation) tests were used, and refinement of the information extracted from the first and second axes showed that the total explained variance rate was $80.94 \%$. 

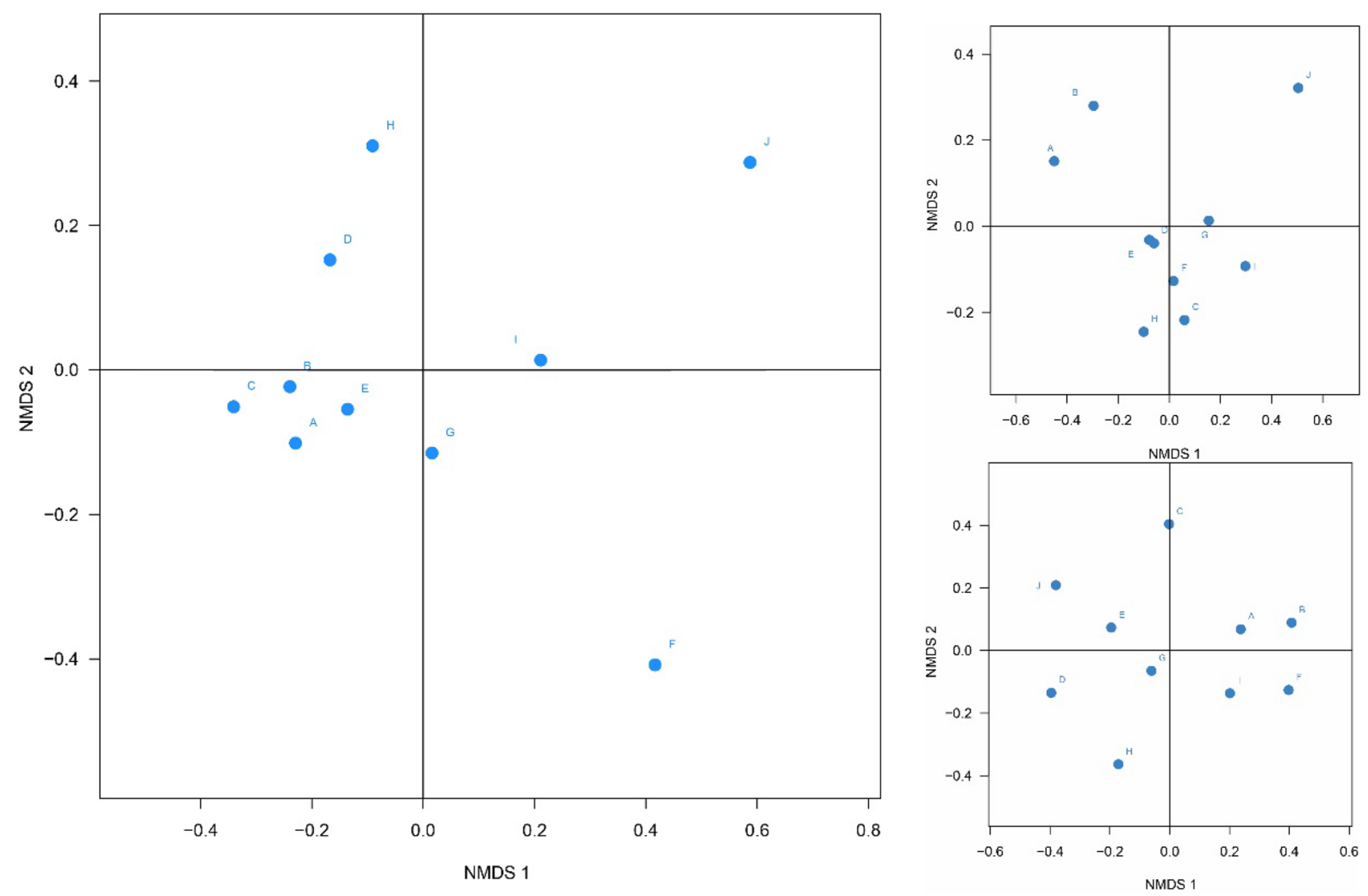

Figure 5. Nonmetric multidimensional scaling map (May, August, and October).
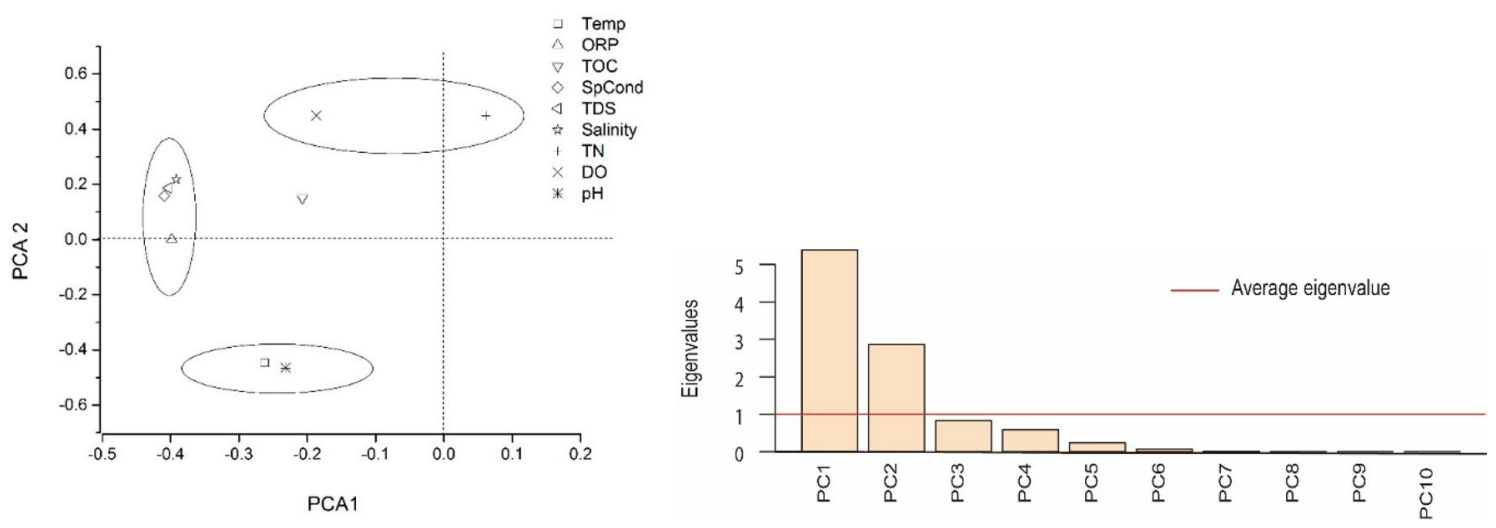

Figure 6. PCA of various environmental factors in the surface-flow constructed wetlands.

\begin{tabular}{|l|l|l|l|l|l|l|}
\hline & Temp & SpCond & DO & pH & ORP & TN \\
\hline ACE & $0.502^{* *}$ & -0.301 & $-0.507^{* *}$ & $0.526^{* *}$ & -0.136 & -0.328 \\
\hline $\mathrm{H}^{\prime}$ & $0.659^{* *}$ & $0.869^{* *}$ & $0.375^{*}$ & $0.570^{* *}$ & $0.924^{* *}$ & -0.221 \\
\hline
\end{tabular}

Table 2. Relationships between biodiversity and environment factors. ${ }^{*}$ Significance at the level of 0.01 ; *Significance at the level of 0.05 . 


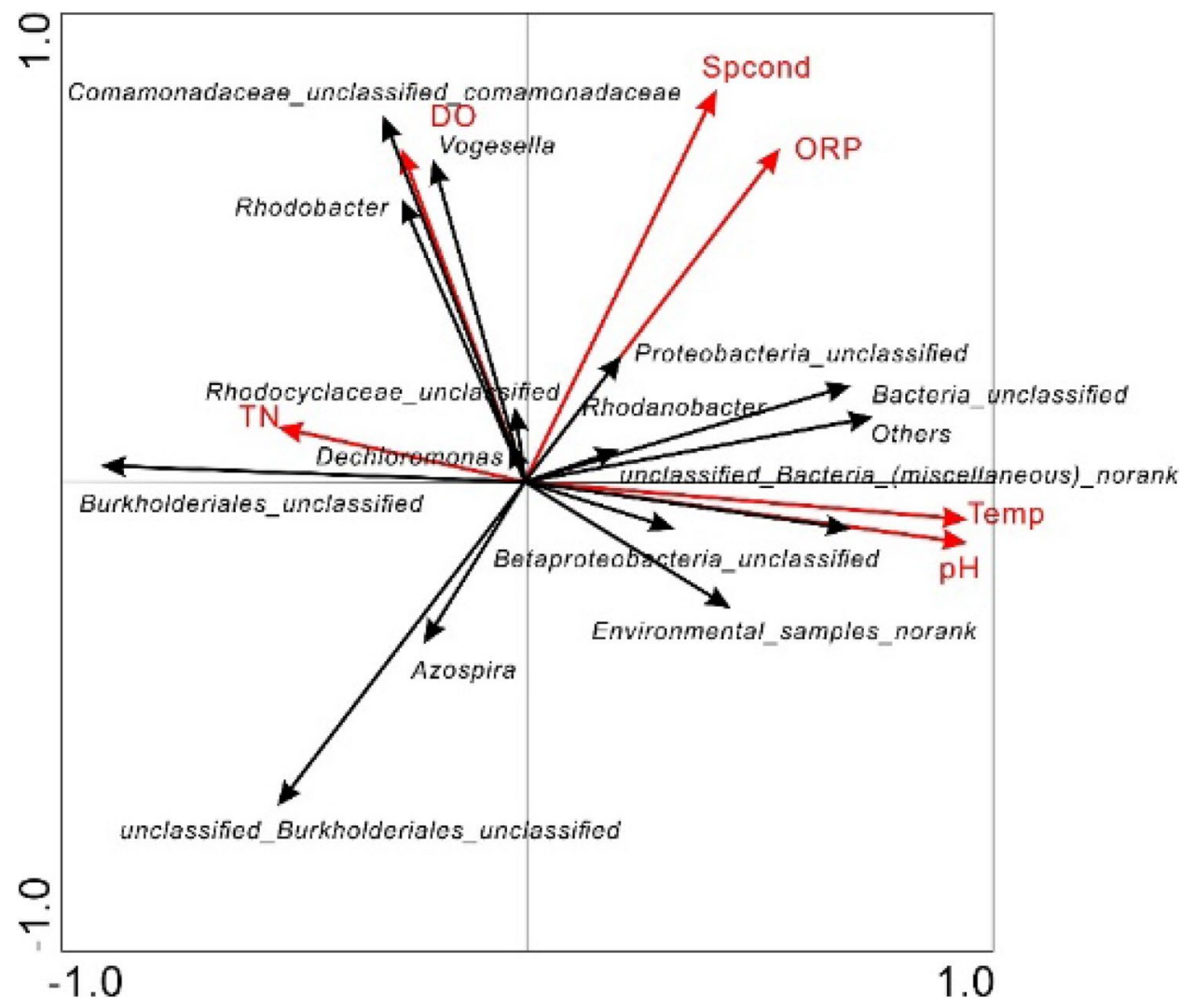

Figure 7. Relationships between denitrifying bacterial community structures and environment factors.

The results showed that all denitrifying bacterial genera were greatly affected by environmental factors, including temperature and $\mathrm{pH}$, and that the effects of SpCond and ORP were similar. The predominance of unclassified bacteria and unclassified Proteobacter could be explained by positive correlations with temperature, $\mathrm{pH}, \mathrm{ORP}$, and SpCond and negative correlations with TN and DO. Dechloromonas showed the opposite trends. In contrast, unranked environmental samples were similar to unclassified Betaproteobacteria, with positive correlations for temperature and $\mathrm{pH}$ but negative correlations for TN and DO.

Denitrifying bacterial diversity is affected by water nutrient elements and other environmental factors. Most denitrifying bacteria were heterotrophic bacteria. In this study, the autotrophic denitrifying bacteria Dechloromonas accounted for a large proportion in each processing unit ${ }^{25,26}$,these bacteria can accumulate phosphate and exhibit denitrification activity, partly explaining the lack of TOC removal in association with the observed TN removal. The SpCond of the water reflected its salinity and could be explained by positive correlations with a high proportion of unclassified Proteobacteria. However, SpCond was not generally correlated with denitrifying bacterial abundance. Our results showed that the water SpCond in surface-flow constructed wetlands affected salinity-related denitrifying bacteria but did not affect other denitrifying bacteria. The ORP was positively correlated with denitrifying bacterial genera that were suitable for survival in a strong oxidizing environment, such as unclassified Proteobacteria.

Different physical and chemical properties can influence the structure of the bacterial community owing to the influence of different species on the living environment ${ }^{27,28}$. In this study, we assessed environmental factors that differed according to season and showed that denitrifying bacteria varied according to some environmental parameters. A comprehensive analysis of the trend of physical and chemical properties of water showed that all parameters except DO and salinity were not highly affected by season and that the trend of the abundances of denitrifying bacteria communities did not change with season along the flow direction of different processing units. However, environmental indicators have a more significant impact on different denitrifying bacteria, which also changes the diversity of denitrifying bacteria community. Accordingly, these results, combined with prediction models of the effects of environmental factors on nitrogen and phosphorus ${ }^{29-31}$, could be used to predict changes in the denitrifying bacterial community structure.

\section{Conclusions}

In this study, we evaluated changes in denitrifying bacteria community structures with variations in environmental and water physicochemical factors. Our results showed that most of the physicochemical factors of water have similar trends in different seasons along the flow direction of different processing units. The denitrifying bacteria community structure was greatly influenced by season, but the variations in abundance were similar in different seasons. The same processing units showed different dominant denitrifying bacteria during different 
seasons, i.e., changes in variations and denitrifying bacteria diversity of communities. The denitrifying bacterial community structures were affected by the second dominant genus over time in the different processing units. The denitrifying bacterial abundance was also correlated with temperature, $\mathrm{DO}$, and $\mathrm{pH}$, and denitrifying bacterial diversity was correlated with temperature, SpCond, $\mathrm{pH}$, and ORP. These finding provide important insights into the diversity and stability of denitrifying bacterial wetland communities.

Received: 18 September 2020; Accepted: 11 January 2021

Published online: 01 March 2021

\section{References}

1. Vymazal, J. The use of sub-surface constructed wetlands for wastewater treatment in the Czech Republic: 10 years experience. Ecol Eng 18(5), 633-646 (2002).

2. Knowles, R. Denitrification. Microbiol Rev 46(1), 43 (1982).

3. Zumft, W. G. Cell biology and molecular basis of denitrification. Microbiol Mol Biol Rev 61(4), 533-616 (1997).

4. Dworkin, M., Falkow, S., Rosenberg, E., Schleifer, K.-H. \& Stackebrandt, E. The prokaryotes: symbiotic associations, biotechnology, applied microbiology Vol. 1 (Springer, Berlin, 2006).

5. Lee, S.-H. \& Kang, H. The activity and community structure of total bacteria and denitrifying bacteria across soil depths and biological gradients in estuary ecosystem. Appl Microbiol Biotechnol 100(4), 1999-2010 (2016).

6. Wang, J. et al. High efficiency of inorganic nitrogen removal by integrating biofilm-electrode with constructed wetland: autotrophic denitrifying bacteria analysis. Bioresour Technol 227, 7-14 (2017).

7. Cao, Q., Wang, H., Chen, X., Wang, R. \& Liu, J. Composition and distribution of microbial communities in natural river wetlands and corresponding constructed wetlands. Ecol Eng 98, 40-48 (2017).

8. Fu, G., Huangshen, L., Guo, Z., Zhou, Q. \& Wu, Z. Effect of plant-based carbon sources on denitrifying microorganisms in a vertical flow constructed wetland. Bioresour Technol 224, 214-221 (2017).

9. Santoro, A. E., Boehm, A. B. \& Francis, C. A. Denitrifier community composition along a nitrate and salinity gradient in a coastal aquifer. Appl Environ Microbiol 72(3), 2102-2109 (2006).

10. Fu, G. et al. The influence of complex fermentation broth on denitrification of saline sewage in constructed wetlands by heterotrophic nitrifying/aerobic denitrifying bacterial communities. Bioresour Technol 250, 290 (2018).

11. Zhang, X. et al. Seasonal variations of soil bacterial communities in Suaeda wetland of Shuangtaizi River estuary, Northeast China. J Environ Sci 97, 45-53 (2020).

12. Throbäck, I. N., Enwall, K., Jarvis, Å. \& Hallin, S. Reassessing PCR primers targeting nirS, nirK and nosZ genes for community surveys of denitrifying bacteria with DGGE. FEMS Microbiol Ecol 49(3), 401-417 (2004).

13. Turcatti, G., Romieu, A., Fedurco, M. \& Tairi, A.-P. A new class of cleavable fluorescent nucleotides: synthesis and optimization as reversible terminators for DNA sequencing by synthesis. Nucleic Acids Res 36(4), e25-e25 (2008).

14. Wang, Q., Garrity, G. M., Tiedje, J. M. \& Cole, J. R. Naive Bayesian classifier for rapid assignment of rRNA sequences into the new bacterial taxonomy. Appl Environ Microbiol 73(16), 5261-5267 (2007).

15. Quast, C. et al. The SILVA ribosomal RNA gene database project: improved data processing and web-based tools. Nucleic Acids Res 41, D590-D596 (2012).

16. Schloss, P. D., Gevers, D. \& Westcott, S. L. Reducing the effects of PCR amplification and sequencing artifacts on 16S rRNA-based studies. PLoS ONE 6(12), e27310 (2011).

17. Kadlec, R. H. Overview: surface flow constructed wetlands. Water Sci Technol 32(3), 1-12 (1995).

18. Logue, J. B. \& Lindström, E. S. Biogeography of bacterioplankton in inland waters. Freshw Rev 1, 99-114 (2010).

19. Nguyen, L. M. Organic matter composition, microbial biomass and microbial activity in gravel-bed constructed wetlands treating farm dairy wastewaters. Ecol Eng 16(2), 199-221 (2000).

20. Nurk, K., Truu, J., Truu, M. \& Mander, Ü. Microbial characteristics and nitrogen transformation in planted soil filter for domestic wastewater treatment. J Environ Sci Health 40(6-7), 1201-1214 (2005).

21. Ibekwe, A., Ma, J., Murinda, S. \& Reddy, G. Bacterial community dynamics in surface flow constructed wetlands for the treatment of swine waste. Sci Total Environ 544, 68-76 (2016).

22. Bellini, M. I., Gutiérrez, L., Tarlera, S. \& Scavino, A. F. Isolation and functional analysis of denitrifiers in an aquifer with high potential for denitrification. Syst Appl Microbiol 36(7), 505-516 (2013).

23. Demanèche, S., David, M. M., Navarro, E., Simonet, P. \& Vogel, T. M. Evaluation of functional gene enrichment in a soil metagenomic clone library. J Microbiol Methods 76(1), 105-107 (2009).

24. Langone, M. et al. Coexistence of nitrifying, anammox and denitrifying bacteria in a sequencing batch reactor. Front Microbiol 5, 28 (2014).

25. Ginige, M. P. et al. Use of stable-isotope probing, full-cycle rRNA analysis, and fluorescence in situ hybridization-microautoradiography to study a methanol-fed denitrifying microbial community. Appl Environ Microbiol 70(1), 588-596 (2004).

26. Liu, Y., Zhang, T. \& Fang, H. H. Microbial community analysis and performance of a phosphate-removing activated sludge. Bioresour Technol 96(11), 1205-1214 (2005).

27. Peralta, R. M., Ahn, C. \& Gillevet, P. M. Characterization of soil bacterial community structure and physicochemical properties in created and natural wetlands. Sci Total Environ 443, 725-732 (2013).

28. Schnecker, J. et al. Effects of soil organic matter properties and microbial community composition on enzyme activities in cryoturbated arctic soils. PLoS ONE 9(4), e94076 (2014).

29. Cui, L. et al. Nitrogen removal in a horizontal subsurface flow constructed wetland estimated using the first-order kinetic model. Water 8(11), 514 (2016).

30. Li, W. et al. Statistical modeling of phosphorus removal in horizontal subsurface constructed wetland. Wetlands 34(3), 427-437 (2014).

31. Li, W., Zhang, Y., Cui, L., Zhang, M. \& Wang, Y. Modeling total phosphorus removal in an aquatic environment restoring horizontal subsurface flow constructed wetland based on artificial neural networks. Environ Sci Pollut Res 22(16), 12347-12354 (2015).

\section{Acknowledgements}

This work was funded by the National Key Research and Development Program of China (2017YFC0506200) and Beijing Hanshiqiao National Wetland Ecosystem Research Station Operation Project.

\section{Author contributions}

All authors reviewed the manuscript. 


\section{Competing interests}

The authors declare no competing interests.

\section{Additional information}

Correspondence and requests for materials should be addressed to L.C.

Reprints and permissions information is available at www.nature.com/reprints.

Publisher's note Springer Nature remains neutral with regard to jurisdictional claims in published maps and institutional affiliations.

(c) (i) Open Access This article is licensed under a Creative Commons Attribution 4.0 International License, which permits use, sharing, adaptation, distribution and reproduction in any medium or format, as long as you give appropriate credit to the original author(s) and the source, provide a link to the Creative Commons licence, and indicate if changes were made. The images or other third party material in this article are included in the article's Creative Commons licence, unless indicated otherwise in a credit line to the material. If material is not included in the article's Creative Commons licence and your intended use is not permitted by statutory regulation or exceeds the permitted use, you will need to obtain permission directly from the copyright holder. To view a copy of this licence, visit http://creativecommons.org/licenses/by/4.0/.

(c) The Author(s) 2021 